\title{
THE ROLE OF MAGNESIUM IN THE CRYSTALLIZATION OF CALCITE AND ARAGONITE IN A POROUS MEDIUM
}

\author{
LURDES FERNÁNDEZ-DÍAZ! ANDREW PUTNIS ${ }^{2 *}$, MANUEL PRIETO, AND CHRISTINE V. PUTNIS² \\ ' Departamento de Cristalografía y Mineralogia, Universidad Complutense de Madrid, 28040 Madrid, Spain \\ 'Deparment of Earth Sciences. University of Cambridge, Cambridge CB2 3EQ. England \\ "Departamento de Geología. Universidad de Oviedo, 33005 Oviedo, Spain
}

\begin{abstract}
Morphological development of calcite crystals is related to supersaturation conditions during growth. Crystallization of calcium carbonate (calcite and aragonite) as well as Mg-calcite was studied under controlled supersaturation conditions by the counter diffusion of $\mathrm{Ca}^{2+}$ and $\mathrm{CO}_{3}{ }^{2-}$ ions through a porous transport medium (a column of silica gel). Under our experimental conditions, where ion transport is constrained to be diffusion controlled, nucleation and growth take place under conditions of high supersaturation, the actual threshold value of the supersaturation depending on the supersaturation gradient. In the pure $\mathrm{CaCO}_{3}$ system, calcite grows at lower supersaturation than aragonite. The calcite develops relatively simple rhombohedra while the aragonite grows as spherulites.
\end{abstract}

Presence of $\mathrm{Mg}^{2+}$ in the interstitial fluid inhibits nucleation, increasing the threshold supersaturation at which crystallization begins. The resulting Mg-calcite crystals show a range of morphologies depending on the Mg content and the supersaturation at the point of crystallization. At high values of supersaturation, up to $15 \mathrm{~mol} \% \mathrm{MgCO}_{3}$ is incorporated into the calcite and the crystals form spheres. At lower supersaturations, $\mathrm{Mg}$ content decreases and morphologies change progressively through a well-defined and reproducible sequence from spheres to dumbbell-like forms to wheat-sheaf-like bundles and eventually single crystals with steep rhombohedral faces. The crystals are compositionally zoned, showing both sector and oscillatory zoning. The compositional evolution is related to the supersaturation and interface roughness during crystal growth.

\section{INTRODUCTION}

Although much research on carbonate petrology has been concerned with the physical and chemical environmental factors that control the morphology, mineralogy, and composition of abiotic calcium carbonates, many aspects of $\mathrm{CaCO}_{3}$ crystallization in natural environments remain obscure. Investigations have focused on the effect of certain ions, mainly $\mathrm{Mg}^{2}$, on different aspects of the crystallization of $\mathrm{CaCO}_{3}$ polymorphs (e.g.. Leitmeir 1910. 1915: Lippmann 1960: Kitano and Hood 1962; Berner 1966; Bischoff 1968; Bischoff and Fyfe 1969: Mucci 1986). It has been pointed out that $\mathrm{Mg}^{2}$ ions in the precipitating solution inhibit $\mathrm{CaCO}_{3}$ nucleation and affect the chemical composition and the mineralogy of the phase that crystallizes. as well as development of the growth. Some authors (Folk 1974; Lahan 1978) have suggested that in natural environments the $\mathrm{Mg} / \mathrm{Ca}$ molar ratio in the fluids and on the surface of the growing crystals is the main control on mineral composition and the morphology of $\mathrm{CaCO}_{3}$. However, many natural examples indicate that, under certain circumstances, $\mathrm{Mg} / \mathrm{Ca}$ molar ratios have very little effect. and growth rate is the controlling parameter (Given and Wilkinson 1985).

A number of investigations have been carried out on the inhibiting role of $\mathrm{Mg}^{2}$ on the nucleation and growth of calcite (McCauley and Roy 1974: Reddy and Nancollas 1976: Reddy and Wang 1980; Nancollas and Sawada 1982: Fallini et al. 1994). Most workers agree that the presence of magnesium retards crystallization of calcite and kinetically favors the formation

\footnotetext{
* Present address: Institut für Mineralogie. Universität Münster, Corrensstr. 24. D-48149 Münster. Germany.
}

of the metastable aragonite polymorph. Calcite inhibition results from processes at the crystal-solution interface, mainly the poisoning of calcite surfaces by magnesium adsorption at active growth sites. The higher solubility of magnesian calcite relative to pure calcite, which leads to a decrease of the thermodynamic driving force for crystallization, may also be important.

The stability of natural magnesian calcites is controversial. According to the results of experimental precipitation studies (Berner 1975; Mucci and Morse 1983), the $\mathrm{MgCO}_{3}$ content of magnesian calcite grown from solutions is determined by the $\mathrm{Mg}^{2+} / \mathrm{Ca}^{2+}$ in the fluids, although temperature and growth rate may exert a certain influence (Kitano and Kanamori 1966). The composition of natural magnesian calcites varies within a wide range (a few mol $\%$ to $20 \mathrm{~mol} \% \mathrm{MgCO}_{3}$ ), and is related to various factors like temperature, $\mathrm{CO}_{3}{ }^{2-}$ concentration, growth rate, and solution saturation (Bathurst 1975, p. 235; Mackenzie et al. 1983; Morse and MacKenzie 1990 and references therein). However, most of these calcitic phases are metastable.

Natural magnesian calcite crystals grown from freshwater generally show a roughly equant rhombic habit, with poorly developed faces, while marine cements with similar contents of $\mathrm{MgCO}_{3}$ can show either fibrous or equant fabric (González et al. 1990). Experimentally precipitated magnesian calcites show a distorted morphology, defined by irregular high-index faces (Reddy and Nancollas 1976), similar to freshwater magnesian calcites. The morphology of minerals is very sensitive to growth conditions. Both supersaturation and the presence of certain impurities can dramatically modify the relative development of different crystallographic faces and hence the final crystal habit. In order to be able to interpret the influence of external factors the different habits must be referred to a theoretical growth form, deduced from structural considerations. Heijnen (1985), by using a PBC (Periodic Bond Chain) analysis, concluded that the theoretical growth form of calcite corresponds to the rhombohedron bounded by $\{1014\}$ faces. An identical conclusion was made by Parker et al. (1993) and Titiloye et al. (1993) by using an atomistic simulation approach. These last authors also found that the kinetic effects of surface-incorporated $\mathrm{Mg}^{2+}$ ions can lead to morphological changes in calcite.

Two of the main reasons for the lack of understanding of most of the problems mentioned above are. on the one hand, the lack of geologically relevant nucleation and growth experiments and, on the other, the use of very simplified models to treat nucleation phenomena in natural environments. The most common approach to natural crystallization problems is based on the direct application of the "classical theory of nucleation", wherein nucleation rate depends on supersaturation and the supersaturation is assumed to be constant. With this approach, the critical supersaturation for nucleation in nature is small. As a result, most phenomena are interpreted as if they happened near equilibrium. However, there is considerable evidence that crystallization in natural environments rarely occurs near equilibrium. Although it has been argued that the inhibiting effect of the presence of certain ions could significantly contribute to the maintenance of metastable supersaturated fluids (Cody 1991), this argument cannot be used to justify all disagreements between theory and observations. An important aspect that is not commonly considered is that supersaturation in nature is never constant. On the contrary, it evolves with time, leading to the development of supersaturation gradients. This situation is not considered by the classical theory of nucleation, but it has been demonstrated that 


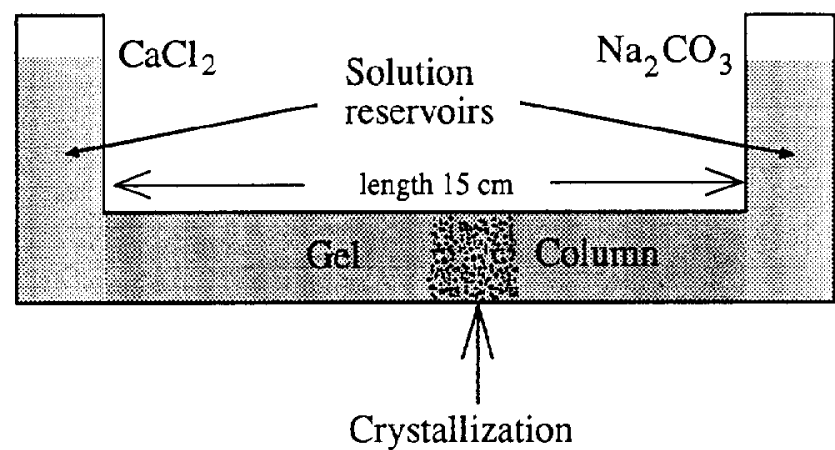

FIc. 1.-Schematic representation of the experimental system. Fluid reservoirs are separated by a column of porous silica gel along which counter diffusion of cations and anions takes place

it markedly affects the actual supersaturation value for nucleation (Prieto et al. 1990; Prieto et al. 1994; Putnis et al. 1995). In an evolving system, the kinetics of nucleation depends on the rate at which the system moves from equilibrium, i.e., the supersaturation rate. Hence. the supersaturation threshold, defined as the supersaturation that can be reached before nucleation occurs, depends on the system evolution. which is mainly determined by the transport properties of the crystallization medium.

In this paper we describe the results of experiments designed to study the crystalization of $\mathrm{CaCO}_{3}$ from a new point of view, paying special attention to the actual value of the supersaturation at nucleation and to the evolution of the system. The crystallization takes place from solution in a column of porous silica gel in which the cations and anions are brought together by counter diffusion from opposite ends of the column. This system allows the diffusion of ions to be measured through the gel column as a function of time and the supersaturation to be calculated at the nucleation site. The effect of $\mathrm{Mg}^{2+}$ on $\mathrm{CaCO}_{3}$ crystallization and growth is observed in experiments in which the factors controlling the crystallization can be established. Furthermore, such crystal growth experiments have been shown to be geologically relevant, reproducing growth ontogenies and morphologies very similar to those found in natural environments (Prieto et al. 1992).

\section{EXPERIMENTAL METHODS}

\section{General Methods}

The silica gel technique has been extensively used as a method of growing crystals of sparingly soluble salts (carbonates, sulfates, etc.) from aqueous solutions (Henisch 1988). The silica hydrogel is a porous medium with a sheet-like structure that forms interconnecting cells. This structure allows the gel to be used as a transport medium where convection and advection are suppressed. Reactants are brought together by diffusion through the gel and. subsequently, nucleation and crystal growth occurs by chemical reaction.

The experimental arrangement used in this work consists in a double diffusion system in which reservoirs of two reagents are separated by a column of polymerized silica gel (Fig. 1). The gel column was $150 \mathrm{~mm}$ long and $9 \mathrm{~mm}$ in diameter. The gel was prepared by acidification of a sodium silicate $\left(\mathrm{Na}_{2} \mathrm{SiO}_{3}\right)$ solution to desired $\mathrm{pH}(5.5)$ by adding $\mathrm{HCl}(1 \mathrm{~N})$. Before it polymerizes to a solid gel, it is poured into a $U$ tube. For the conditions established here. the silica hydrogel contains about $95.6 \%$ water filling the pores. The gelling process involves formation of $\mathrm{NaCl}$ as a soluble by-product.

Calcium carbonate can be prepared by a number of different chemical reactions. Since sodium and chlorine are already present in the interstitial solution, it is advantageous to have them as part of the reagents in order
TABLE 1.-Initial concentration and experimental data for the nucleation of calcite

\begin{tabular}{|c|c|c|c|c|c|}
\hline \multicolumn{6}{|l|}{ A) Pure } \\
\hline $\begin{array}{c}\text { Initial } \\
\text { Concentration } \\
\mathrm{C}_{\mathrm{A}}-\mathrm{C}_{\mathrm{B}}\end{array}$ & $\begin{array}{l}\text { Waiting } \\
\text { Time } \\
\text { (hours) }\end{array}$ & $\begin{array}{l}\text { Precipitate } \\
\text { Location } \\
\text { (slices) }\end{array}$ & $\begin{array}{l}\text { Supersaturation } \\
\text { Threshold }\end{array}$ & $\begin{array}{c}\text { Supersaturation } \\
\text { Rate }\end{array}$ & {$\left[\mathrm{Ca}^{2+}\right],\left[\mathrm{CO}_{3}=\right]$} \\
\hline $\begin{array}{c}1 \mathrm{M}-1 \mathrm{~N} \\
0.5 \mathrm{M}-0.5 \mathrm{~N} \\
0.3 \mathrm{M}-0.3 \mathrm{~N}\end{array}$ & $\begin{array}{l}336 \\
422 \\
504\end{array}$ & $\begin{array}{l}10-11 \\
10-11 \\
10-11\end{array}$ & $\begin{array}{l}2300 \\
1700 \\
1000\end{array}$ & $\begin{array}{r}12.1 \\
9.1 \\
4.4\end{array}$ & $\begin{array}{l}1.3-0.5 \\
0.1-1.6 \\
1.0-1.7\end{array}$ \\
\hline \multicolumn{6}{|l|}{ B) $625 \mathrm{ppm} \mathrm{Mg}$} \\
\hline $\begin{array}{c}\text { Initial } \\
\text { Concentration } \\
\mathrm{C}_{\mathrm{A}}-\mathrm{C}_{\mathrm{B}}\end{array}$ & $\begin{array}{l}\text { Waiting } \\
\text { Time } \\
\text { (hours) }\end{array}$ & $\begin{array}{l}\text { Precipitate } \\
\text { Location } \\
\text { (slices) }\end{array}$ & $\begin{array}{l}\text { Supersaturation } \\
\text { Threshold }\end{array}$ & $\begin{array}{c}\text { Supersaturation } \\
\text { Rate }\end{array}$ & {$\left[\mathrm{Ca}^{2+}\right]\left[\mathrm{CO}_{3}{ }^{-}\right]$} \\
\hline $\begin{array}{c}1 \mathrm{M}-1 \mathrm{~N} \\
0.5 \mathrm{M}-0.5 \mathrm{~N} \\
0.3 \mathrm{M}-0.3 \mathrm{~N}\end{array}$ & $\begin{array}{l}432 \\
528 \\
600\end{array}$ & $\begin{array}{l}10-11 \\
10-11 \\
10-11\end{array}$ & $\begin{array}{l}3400 \\
2100 \\
1400\end{array}$ & $\begin{array}{r}14.8 \\
8.9 \\
4.5\end{array}$ & $\begin{array}{l}1.6-1.7 \\
0.4-1.8 \\
0.9-1.2\end{array}$ \\
\hline \multicolumn{6}{|l|}{ C) $1250 \mathrm{ppm} \mathrm{Mg}$} \\
\hline $\begin{array}{c}\text { Initial } \\
\text { Concentration } \\
\mathrm{C}_{\mathrm{A}}-\mathrm{C}_{\mathrm{B}}\end{array}$ & $\begin{array}{c}\text { Waiting } \\
\text { Time } \\
\text { (hours) }\end{array}$ & $\begin{array}{l}\text { Precipitale } \\
\text { Location } \\
\text { (slices) }\end{array}$ & $\begin{array}{l}\text { Supersaturation } \\
\text { Threshold }\end{array}$ & $\begin{array}{l}\text { Supersaturation } \\
\text { Rate }\end{array}$ & $\left.\left.\left[\mathrm{Ca}^{-}\right] \cdot\right] / \mathrm{CO}_{3}^{-}\right]$ \\
\hline $\begin{array}{c}1 \mathrm{M}-1 \mathrm{~N} \\
0.5 \mathrm{M}-0.5 \mathrm{~N} \\
0.3 \mathrm{M}-0.3 \mathrm{~N}\end{array}$ & $\begin{array}{l}432 \\
600 \\
744\end{array}$ & $\begin{array}{l}10-11 \\
10-11\end{array}$ & $\begin{array}{l}3400 \\
2500 \\
7000\end{array}$ & $\begin{array}{r}14.8 \\
8.4 \\
3.8\end{array}$ & $\begin{array}{l}1.6-1.8 \\
0.4-2.0 \\
06-16\end{array}$ \\
\hline
\end{tabular}

to minimize the number of foreign ions present. In this work, the following reaction was used:

$$
\mathrm{Na}_{2} \mathrm{CO}_{3}+\mathrm{CaCl}_{2} \rightarrow \mathrm{CaCO}_{3}+2 \mathrm{NaCl}
$$

The two source reservoirs were therefore filled with $\mathrm{CaCl}_{2}$ and $\mathrm{Na}_{2} \mathrm{CO}_{3}$ solutions, respectively (Table 1). Separate experiments were carried out to study the influence of the presence of $\mathrm{Mg}^{2+}$ in the aqueous solution on the nucleation and growth of $\mathrm{CaCO}_{3}$. Small concentrations of magnesium (625 and $1250 \mathrm{ppm}$ ) were added to the sodium silicate solution during the gel preparation so that the gel column had a homogeneous concentration of additive. All the experiments were conducted at $25^{\circ} \mathrm{C}$.

Nucleation behavior was studied by measuring the location of the first precipitate, the nucleation density. and the experimental waiting period (the time taken for the first crystallites to be observed under a magnification of $\times 500$ ) . The growth evolution of the crystals was monitored by optical microscopy. A month after nucleation, the crystals were recovered by dissolving the gel in a $\mathrm{NaOH}$ (1M) solution. Their morphology was studied by scanning electron microscopy. Samples representing the different morphologies were hand-picked and studied by $\mathrm{X}$-ray diffraction. The X-ray diffraction study was carried out in a Guinier powder camera using a 4 $\mathrm{mm}$ fine-focus $\mathrm{X}$-ray tube and a quartz monochromator for $\mathrm{Cu} \mathrm{K}_{\mathrm{cx}}$ radiation. Powder lines could be measured to $\pm 0.01^{\circ} 2 \theta$ by using an Enraf-Nonius FR $508 \mathrm{~V}$ Guinier viewer. The lattice parameters of the different samples were refined using between 12 and 22 reflections and a least-squares program CELL on a VAX 2000. The Mg content of the crystals and the $\mathrm{Mg}$ distribution were studied by electron microprobe and $\mathrm{X}$-ray imaging using the $\mathrm{Ca} \mathrm{K}_{\alpha}$ and $\mathrm{Mg} \mathrm{K}$ emissions from the sample.

\section{Mass Transfer and Supersaturation}

Before the experiments start, the gel column has a homogeneous $\mathrm{pH}$ (5.5) and the concentration of the reagents at any point of the diffusion column is zero. However, diffusion of the different chemical species immediately forms gradients of $\mathrm{pH}$ and concentration along the gel column. Both the $\mathrm{pH}$ and concentration profiles of all ions are a function of diffusion time, and the values are known from previous work (Prieto et al. 1988; Prieto et al. 1989; Fernández-Díaz 1989). These papers also describe details of the analytical methods and the experimental errors involved. This information, together with the data on the position and time of the first appearance of crystallites, allows calculation of the supersaturation of the interstitial solution with respect to the different phases of calcium carbonate at the nucleation time. 


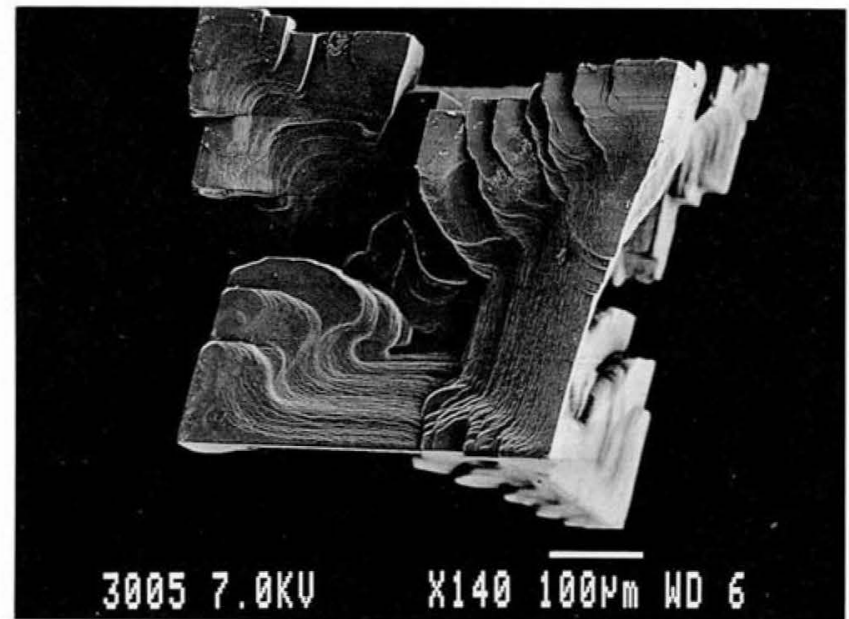

Fic. 2.-Scanning electron micrograph of a calcite crystal showing dendritic growth in the early stages of morphological development

The expression

$$
\beta=a\left(\mathrm{Ca}^{2+}\right) a\left(\mathrm{CO}_{3}{ }^{2-}\right) / K_{s p}
$$

was used to estimate the supersaturation $\beta$, where $a\left(\mathrm{Ca}^{2+}\right)$ and $a\left(\mathrm{CO}_{3}{ }^{2-}\right)$ are the activities of the free ions in the solution and $K_{s p}$ is the thermodynamic solubility product. The same expression can be used to determine the supersaturation of the system with respect to the three calcium carbonate polymorphs by changing the value of the solubility product ( $K_{\mathrm{sp} \text { calcite }}$ $=10^{8.35} ; K_{s p \text { aragonite }}=10^{-8.22}: K_{s p \text { vaterite }}=10^{-7.726}$ ).

The activity coefficients of $\mathrm{Ca}^{2+}$ and $\mathrm{CO}_{3}{ }^{2-}$ were computed by using the Debye-Hückel formula. This method of calculation, requiring use of a suitable aqueous speciation model. has been extensively explained for other systems in previous papers (Prieto et al. 1989, 1990). In this case we have considered the following species: Charged species: $\mathrm{HCO}_{3}{ }^{-}, \mathrm{CO}_{3}{ }^{2-}$, $\mathrm{NaCO}_{3}{ }^{+}, \mathrm{Na}^{+}, \mathrm{CaOH}^{+}, \mathrm{CaHCO}_{3}{ }^{+}, \mathrm{Ca}^{2+}, \mathrm{OH}$; uncharged species: $\mathrm{H}_{2} \mathrm{CO}_{3}$, $\mathrm{NaHCO}_{3}, \mathrm{NaOH}, \mathrm{CaCO}_{3}$.

\section{EXPERIMENTAL RESULTS}

\section{Crystallization of $\mathrm{CaCO}_{3}$ in the Absence of $\mathrm{Mg}^{2+}$ Ions}

Precipitate Location and Waiting Time.-Table 1A shows the results of calcium carbonate nucleation in the absence of $\mathrm{Mg}^{2+}$ for various concentrations of the mother solutions. The waiting time and location of the first precipitates are the most important data needed to understand the behavior of crystal nucleation in diffusing-reacting systems. There is a clear relationship between the waiting period for nucleation and the concentration of the mother solutions, highly concentrated mother solutions resulting in short waiting periods.

The location of the first precipitate is also modified as a function of the initial concentration of the reagents. In all the experiments, crystallization begins in the region of the column where, at nucleation time, the $\left[\mathrm{Ca}^{2+}\right]$ $\left[\mathrm{CO}_{3}{ }^{2-}\right]$ ratio has a value close to one. This behavior agrees with the results obtained by Fernández-Díaz (1989) and Prieto et al. (1989) for crystallization of other carbonates in gels.

The value of supersaturation at the time and location of the first precipitates also depends markedly on the boundary conditions of the system and can vary within a very wide range. For example, in the case of mother solutions $\mathrm{CaCl}_{2}(\mathrm{IM})-\mathrm{Na}_{2} \mathrm{CO}_{3}(1 \mathrm{~N})$, the supersaturation at the nucleation time and location had a value of 2300 , while its value was 1000 when the mother solutions were $\mathrm{CaCl}_{2}(0.3 \mathrm{M})-\mathrm{Na}_{2} \mathrm{CO}_{3}(0.3 \mathrm{~N})$. Highly concentrated mother solutions systematically produce high supersaturation levels. Al-

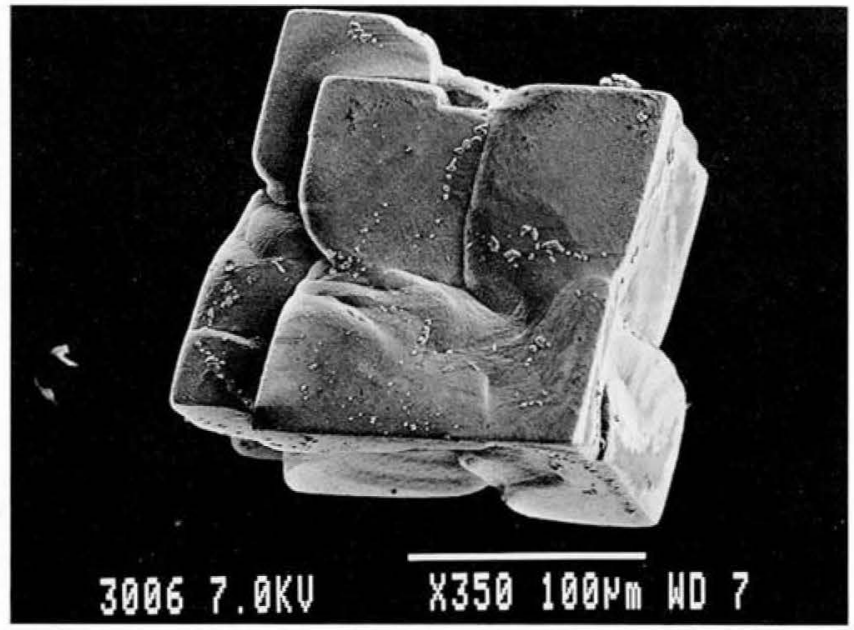

FIG. 3.-Rhombohedral crystal of calcite with non-flat wavy faces.

though the mother solutions have relatively high concentrations, the slow diffusivity of the ions through the porous silica gel ensures that the ion concentrations at the time and place of nucleation of the carbonate are very much lower. For example, the supersaturation value of 1000 mentioned above corresponds to concentrations of $\mathrm{Ca}^{2+}$ and $\mathrm{CO}_{3}{ }^{2-}$ of less than 20 millimoles/liter at nucleation, which is in the same range as the ion concentrations in pore waters in sedimentary basins (Warren and Smalley 1994).

Crystallization Sequence and Crystal Habits.-As mentioned above, although calcite (rhombohedral) is the stable phase of calcium carbonate at low temperature, its crystallization is complicated by the possibility of metastable nucleation of the other two polymorphs, aragonite (orthorhombic), and vaterite (hexagonal). With the experimental setup we used in this work, the first crystals formed are always calcite. Calcite crystals initially appear as well faceted single crystals with rhombohedral habit, defined by singular $\{10 \overline{1} 4\}$ faces. As growth progresses, $\{10 \overline{1} 4\}$ faces develop large steps and crystals show signs of dendritic growth (Fig. 2). With time, these hopper crystals take the rhombohedral form with non-flat wavy faces, the center of the faces being slightly depressed. Morphologies such as shown in Figure 3 arise.

The progress of crystallization produces a broadening of the region of the column occupied by crystals. Some time after nucleation of calcite, spherulites of aragonite form in the zone of the precipitation region closer to the reservoir of $\mathrm{Na}_{2} \mathrm{CO}_{3}$ (Fig. 4). The spherulites are built by individual needle-shaped crystallites, elongated along the $c$ axis in a radial arrangement. These crystallites have orthorhombic prismatic faces $\{010\}$ and $\{110\}$, and aragonite-type twins. The size of the spherulites is variable, 150-200 $\mu \mathrm{m}$.

\section{Influence of $\mathrm{Mg}^{2+}$ Ions on the Crystallization of $\mathrm{CaCO}_{3}$}

The presence of small concentrations of magnesium in the interstitial solution during calcium carbonate crystallization mainly has an inhibiting effect on nucleation. This effect can be studied by noting the changes in the observed parameters used to characterize the crystallization of calcium carbonate in a pure medium. In a nonhomogeneous time-dependent system like ours, the inhibiting effect changes the waiting time and details of nucleation. These alterations can affect the regularity of the process and/ or introduce changes in the crystallization sequence.

Precipitation Location and Waiting Period.-Table 1B, C summarizes the experimental results corresponding to calcium carbonate crystallization in gels doped with magnesium. Comparison of Table $1 \mathrm{~B}, \mathrm{C}$ with Table $1 \mathrm{~A}$ 


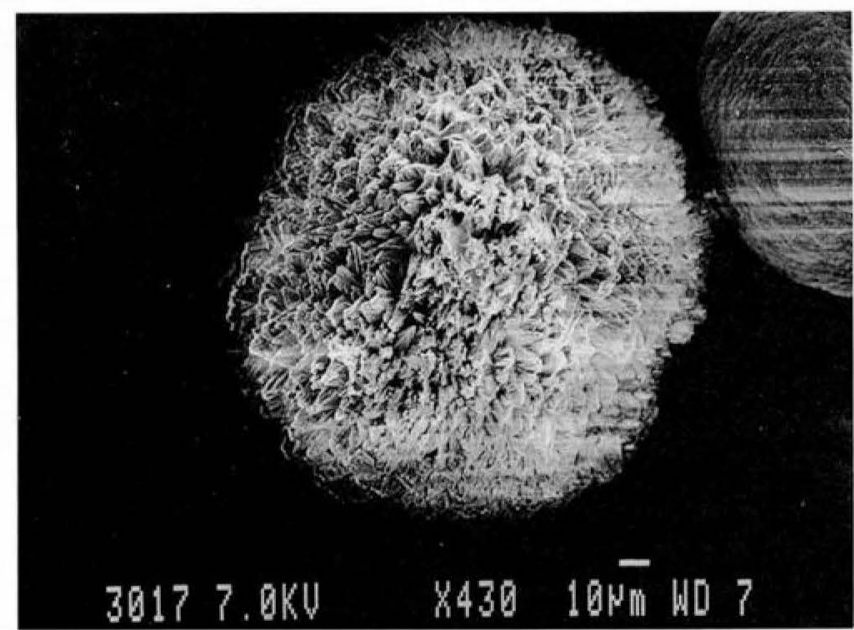

FiG. 4.-Scanning electron micrograph of an aragonite spherulite grown in an $\mathrm{Mg}$-free interstitial solution.

shows that the presence of magnesium increases the waiting period for nucleation. This effect becomes more obvious with increasing $\mathrm{Mg}$ concentration. However, proportionally large increases of $\mathrm{Mg}^{2+}$ concentration result in relatively small increases of the waiting period. Moreover, the effecriveness of magnesium in increasing the waiting period decreases with the increase of the concentration of the mother solutions.

No differences can be distinguished between the location in the column of the first precipitates when experiments are carried out in the absence of $\mathrm{Mg}^{2}$ - compared to experiments in gels doped with $\mathrm{Mg}^{2+}$. The nucleation zone is constrained in all the experiments to the region of the diffusion column where the $\left.\left[\mathrm{Ca}^{2+}\right] / \mathrm{CO}_{3}{ }^{2-}\right]$ ratio is close to one. Magnesium does not affect this aspect of the process.

A consequence of the fact that the presence of magnesium increases the waiting time is that the supersaturation at the nucleation time and location will also be much higher than in a pure medium. As can be observed by comparing Table $1 A$ and Tables $1 B$ and $C$, in the presence of this ion supersaturation is increased by a factor of 1.5 to 2 . depending on the concentration of magnesium. For a specific concentration of magnesium, supersaturation at the nucleation time depends on the concentration of the mother solutions.

Crystallization Sequence and Crystal Habits.-The presence of magnesium in the interstitial fluid does not modify the crystallization sequence of the phases. X-ray diffraction of the first crystals that precipitate confirms that their mineral composition corresponds to calcite, independently of the concentration of magnesium in the surrounding solution. Subsequently, aragonite crystallizes and grows as spherulites identical to the those formed in pure gels. However. the time elapsed between calcite and aragonite nucleation increases slightly with magnesium concentration.

The presence of magnesium has a striking effect on the morphology of the calcite crystals. Calcite crystallization starts with precipitation of spheres with a very rough surface. These spheres are generally about 200 $\mu \mathrm{m}$ in diameter, although some grow to as much as $300 \mu \mathrm{m}$ (Fig. 5A). The progress of crystallization produces the sequential appearance of a wide variety of morphologies, from dumbbell-like forms to bundle or sheaflike crystals. within the gel (Fig. 5B-F). All intermediate morphologies between these two extremes have been observed. Crystal sizes ranged from $150 \mu \mathrm{m}$ to $500 \mu \mathrm{m}$. Even though surfaces are in general very rough, somewhat defined crystal faces can be identified in late bundle-like crystals (Fig. 5F). The sequence ends with the formation of morphologies that clearly correspond to single crystals (Fig. $5 \mathrm{G}-\mathrm{H}$ ). These single crystals show very steep rhombohedral faces. probably $\{02 \overline{2} 1\}$, although poorly defined.
The tips of the crystals generally appear open, but they can be roughly closed by $\{10 \bar{\top} 4\}$ rhombohedral faces. The steep rhombohedral faces show striations, and numerous steps that can be misoriented.

In all the experiments with magnesium in the interstitial fluid, the morphologies described above are distributed according to the same pattern within the precipitation region. The spheres occupy the extreme of the region close to the $\mathrm{Na}_{2} \mathrm{CO}_{3}$ deposit, while the single crystals with steep faces occupy the extreme close to the $\mathrm{CaCl}_{2}$ source. The intermediate morphologies are distributed between the two extremes (Fig. 8).

Chemical Analysis.-Lattice parameter refinements of calcite samples representing the different morphologies are shown in Table 2. Sample 1 corresponds to calcite grown in absence of magnesium (Fig. 2) and Samples 2 and 3 correspond to calcite crystals grown in gels doped with magnesium. Sample 2 includes crystals with the more rhombohedral-shaped morphologies such as in Figure $5 \mathrm{G}$ and $\mathrm{H}$, while Sample 3 is predominantly made up of the rounded grains such as in Figure $5 \mathrm{~A}$ and $\mathrm{B}$. Although the three samples were confirmed to be calcite, there are significant differences in the unit-cell dimensions between the different morphologies. These differences could be due to the magnesium content in the calcite. The relationship between the unit-cell parameters and the composition of magnesian calcite (Bischoff et al. 1983) was used to determine the mole fraction $\mathrm{MgCO}_{3}$ in our samples. Both Samples 2 and 3 were confirmed to be lowmagnesium calcites. Although the powder lines were rather broad, suggesting the possibility of $\mathrm{Mg}$ zoning, the approximate compositions of the two samples were found to be $1.5 \mathrm{~mol} \% \mathrm{MgCO}_{3}$ (Sample 2) and $5 \mathrm{~mol}$ \% $\mathrm{MgCO}_{3}$ (Sample 3).

Quantitative electron microprobe analysis confirmed the striking relationship between the morphology of the crystals and the magnesium content, as well as the existence of $\mathrm{Mg}$ zoning. The calcites progressively increase in average $\mathrm{Mg}$ content from morphologies such as shown in Figure $5 \mathrm{H}$ to those shown in Figure 5A. Figure 6A shows a polished section through a calcite grain with morphology similar to that shown in Figure $5 \mathrm{~F}$, imaged using the $\mathrm{Ca} \mathrm{K}_{\alpha} \times$ rays emitted from the sample to reveal the zoning. The darker parts of the crystal are richer in $\mathrm{Mg}$ than the lighter parts, and in the crystal shown in Figure 6A the variation is from a maximum measured $\mathrm{Mg}$ content of $7.5 \mathrm{~mol} \% \mathrm{MgCO}_{3}$ at the center of the grain, to less than $1 \mathrm{~mol} \% \mathrm{MgCO}_{3}$ at the edges. The $\mathrm{Mg}$ distribution also shows sector zoning forming an "hour-glass" pattern. A similar distribution of $\mathrm{Mg}$ exists in all the grains. Morphologies such as shown in Figure $5 \mathrm{C}$ show maximum $\mathrm{Mg}$ contents at the center of $\sim 8.2 \mathrm{~mol} \% \mathrm{MgCO}_{3}$,

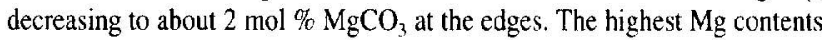
are in the round grains (Fig. 5A), and these show the most complex zonation. One example is shown in the X-ray images shown in Figure $6 \mathrm{~B}$ and $\mathrm{C}$. In Figure $6 \mathrm{~B}$ the central parts of the grain have a magnesium content of around $15 \mathrm{~mol} \% \mathrm{MgCO}_{3}$, with the edges at $3 \mathrm{~mol}_{\%} \mathrm{MgCO}_{3}$. The zoning is also oscillatory, a feature that can be more clearly seen when imaged using the contrast-enhanced image using $\mathrm{Mg} \mathrm{K}_{\alpha} \mathrm{X}$ rays (Fig. $6 \mathrm{C}$ ). The aragonite spherulites contain very little $\mathrm{Mg}$, typically less than $1 \mathrm{~mol}$ $\% \mathrm{MgCO}_{3}$.

The apparent discrepancy between the composition of Mg-calcites deduced from the lattice parameters and that directly obtained from electron microprobe analysis suggests that factors other than $\mathrm{Mg}$ content may affect the lattice parameters, although the chemical zoning also complicates determination of lattice parameters.

\section{DISCUSSION}

In this discussion we focus on the principal issues raised by the results described above, specifically those factors relevant to nucleation and subsequent crystal growth of $\mathrm{CaCO}_{3}$ in the absence and in the presence of $\mathrm{Mg}^{2+}$ ions. 

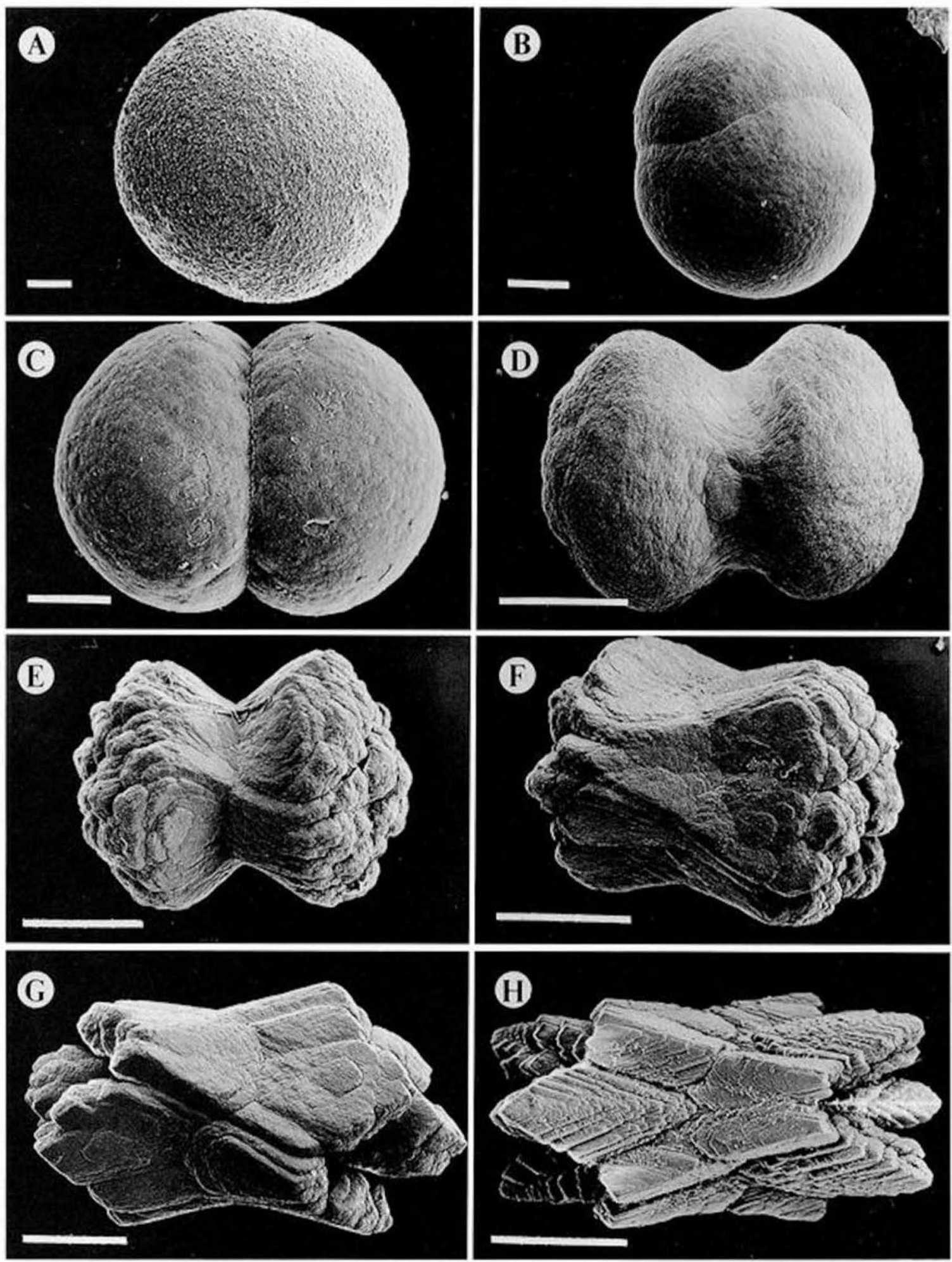

FiG. 5.-Scanning electron micrographs of Mg-calcites. The sequence shows the morphological evolution as a function of the average $\% \mathrm{MgCO}_{3}$ content and supersaturation. The spherical forms such as in $\mathbf{A}$ have the highest $\mathbf{M g}$ content, and the rhombohedral forms have the lowest $\mathrm{Mg}$ content. In $\mathbf{A}-\mathbf{C}$ the scale bar is $20 \mu \mathrm{m}$; in $\mathbf{D}$ $\mathbf{H}$ the scale bar is $100 \mu \mathrm{m}$. 

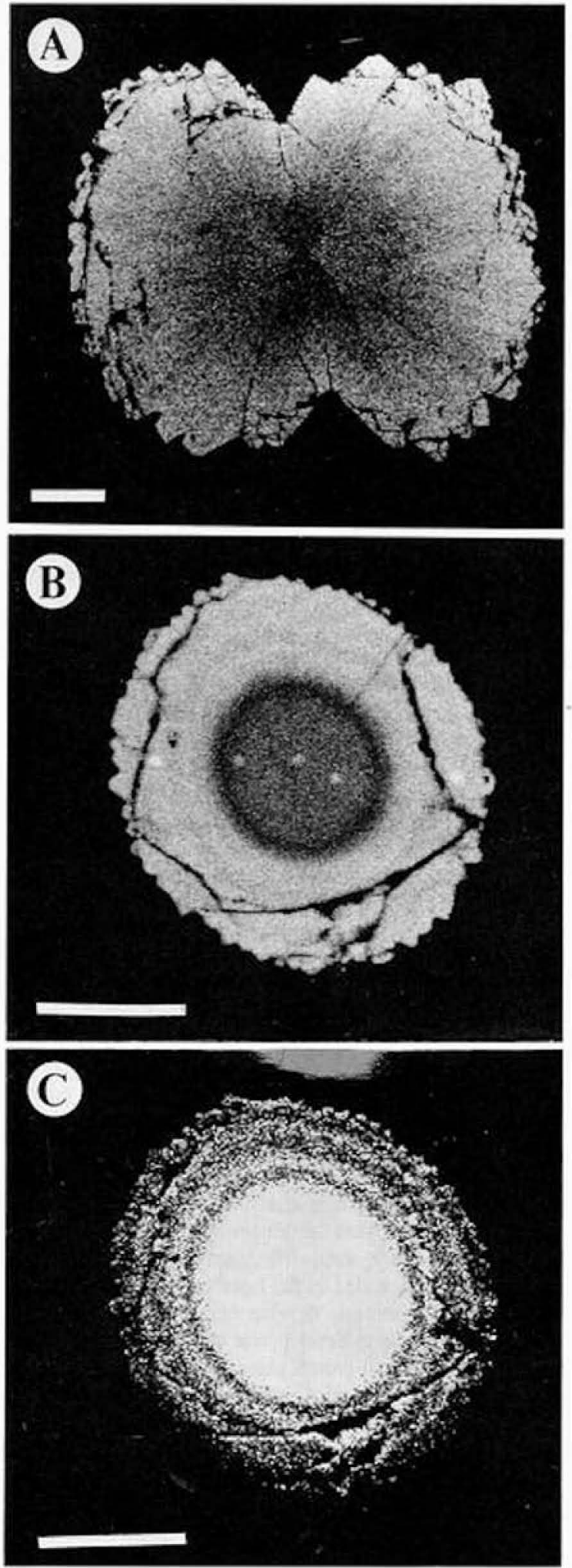

FIG. 6.-X-ray images of polished sections of Mg-calcite. A) An Mg-calcite grain with morphology similar to that in Figure 5F. imaged using the $\mathrm{Ca}_{\mathrm{s}} \mathrm{X}$-ray emission, the lightest parts showing the highest $\mathrm{Ca}$ concentration. The dark zoning pattern is the distribution of $\mathrm{Mg}$. B) An Mg-calcite grain similar to that in Figure $5 \mathrm{~A}$, imaged using $\mathrm{Ca} \mathrm{K}_{u} \mathrm{X}$ rays. A high-Mg zone in the center of the grain gives way during growth to a lower Mg concentration with weak oscillatory zoning. C) The
TABLE 2.-Lattice parameter refinements of calcite crnstals

\begin{tabular}{|c|c|c|c|c|c|}
\hline \multirow[b]{2}{*}{ Sample } & \multirow[b]{2}{*}{ Phase } & \multicolumn{3}{|c|}{ Lattice Parameter ( $\hat{A})$} & \multirow{2}{*}{$\begin{array}{c}\text { Cell } \\
\text { Volume } \\
\left(\tilde{A}^{3}\right)\end{array}$} \\
\hline & & d & $b$ & c & \\
\hline 1 & Pure Calcite & 4.9895 & 4.9895 & 17.0679 & 367.975 \\
\hline 2 & Mg-Calcite $(<1.8 \%)$ & 4.9852 & 4.9852 & 17.0395 & .366 .7 .70 \\
\hline 3 & $\mathrm{Mg}$-Calcite $(3.9<\%<5.7)$ & $\$ .9676$ & 4.9676 & 16.9842 & 362.967 \\
\hline
\end{tabular}

\section{Nucleation and Growth of $\mathrm{CaCO}_{3}$ in the Absence of $\mathrm{Mg}^{2+}$ lons}

Nucleation.-In porous systems, where mass transfer mainly occurs by ionic diffusion, high degrees of supersaturation are reached before nucleation occurs, especially when the salt that crystallizes is sparingly soluble (Putnis et al. 1995). In the classical theory of homogeneous nucleation from solutions, the concept of "critical supersaturation" $\beta$ is used to define the supersaturation value above which the nucleation rate $J$ rapidly increases. Critical supersaturation marks the boundary between the metastable state and the labile state. Normally, critical supersaturation is defined as the supersaturation value that corresponds to a nucleation rate $J$ equal to one nucleus $\mathrm{cm}^{-3} \mathrm{~s}^{-1}$ (Walton 1969).

The concept of critical supersaturation has been developed over many decades by crystal growers to explain the nucleation behavior of systems where supersaturation is maintained constant and uniform. However, in diffusing-reacting systems, such as in the experimental system described here as well as in geological systems where mass transfer is restricted and is mainly diffusion controlled, critical supersaturation is a meaningless concept. In these systems the $\mathrm{pH}$, the concentration of all ions, and thus the supersaturation all change continuously at any point in space and time. The systems are evolutionary and inhomogeneous. The development of supersaturation gradients has an important consequence: nucleation begins at a supersaturation level that depends on the boundary conditions (Prieto et al. 1990). In the case of our experimental setup, the boundary conditions are the initial concentration of the mother solutions and the length of the diffusion column. These two factors control the supersaturation gradients in the interstitial solution.

To understand nucleation behavior in this type of system, an alternative concept was developed: the threshold supersaturation $\beta_{t h}$. This is a dynamic concept of supersaturation, which is related to the evolutionary history of the system and has to be applied whenever supersaturation gradients exist. Recent work by Prieto et al. (1994) and Putnis et al. (1995) has shown that the actual threshold supersaturation value for each experiment depends on the supersaturation rate $R_{\beta}$, i.e., the rate at which the system is moving away from equilibrium. These authors carried out nucleation experiments in gels using different initial concentrations of the reactants. From measurements of concentration profiles, the supersaturation profiles through the gel column were computed as a function of diffusion time for a range of starting conditions. At the position in the column where nucleation occurs, successive values of the supersaturation as a function of time, $\beta(t)$, were then determined. The supersaturation threshold value $\beta_{t h}$ for each experiment was then obtained by interpolating the supersaturation value at the nucleation time and location. The supersaturation rate $R_{\beta}$ is the value of the derivative $d \beta / d t$ of $\beta(t)$, for $t=t_{w}$, the waiting time.

These calculations showed that the metastability level, i.e., the supersaturation threshold value, increases with supersaturation rate. An empirical relationship governing this dependence was found to be $R_{\beta}=K\left(\beta_{t h}\right)^{m}$, where $K$ and $m$ are empirical coefficients. This relationship has been verified for a number of sulfates and carbonates, and also applies when the

$\leftarrow$

same grain as in $\mathbf{A}$ but imaged using $\mathrm{Mg} \mathrm{K}_{\alpha} \mathrm{X}$ rays and contrast-enhanced to show the $\mathrm{Mg}$ oscillatory zoning at the crystal margin. The scale bar is $50 \mu \mathrm{m}$ long. 

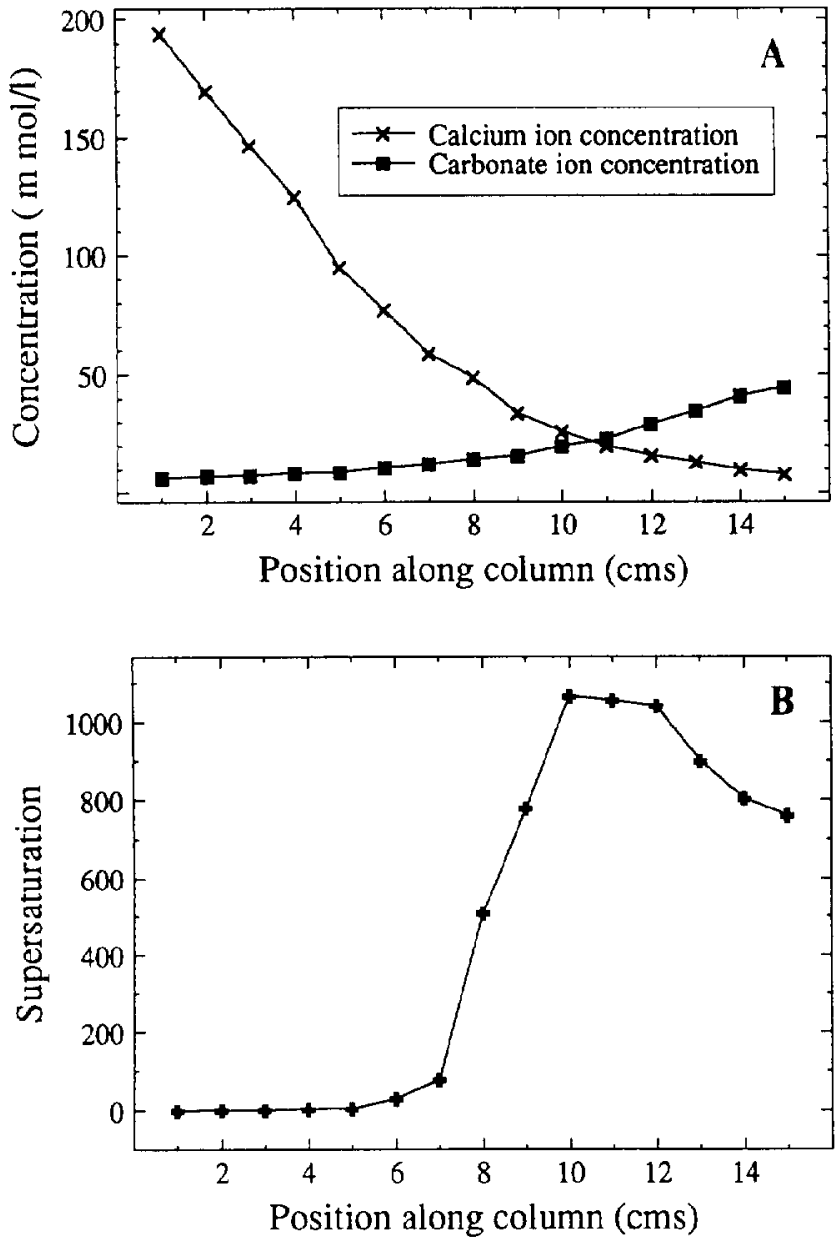

Fik. 7.-A) Concentration profiles of $\mathrm{Ca}^{2+}$ and $\mathrm{CO}_{3}{ }^{2-}$ ions along the diffusion column at nucleation time $(600 \mathrm{hr})$ with starting solutions of $0.3 \mathrm{M} \mathrm{CaCl}_{2}$ and $0.3 \mathrm{~N}$ $\mathrm{Na}_{2} \mathrm{CO}_{3}$. B) Supersaturation profile along the column at the nucleation time.

system is driven to very high supersaturations by the presence of inhibitors (Putnis et al. 1995). Table 1 illustrates such behavior. For a gel column 15 $\mathrm{cm}$ long, nucleation occurred at a supersaturation value of 2300 when $\mathrm{CaCl}_{2}$ (I M)- $\mathrm{Na}_{2} \mathrm{CO}_{3}$ (IN) mother solutions were used. However, when the concentrations of the mother solutions were $\mathrm{CaCl}_{2}(0.3 \mathrm{M})-\mathrm{Na}_{2} \mathrm{CO}_{3}$ $(0.3 \mathrm{~N})$ the supersaturation had a value of 1000 at the nucleation time and location. In the first case, the supersaturation rate was 12 , while in the second case it was 4 . The much smaller supersaturation rate in the second experiment determines that, even though the waiting period was longer, nucleation occurs under much lower supersaturations. Note again, however, that in both cases the concentrations of the reacting ions in the interstitial solution have geologically realistic values (Fig. 7).

The supersaturation rate is not homogeneous for each experiment: at any given time it has a different value at each point of the gel column. Thus, it is possible to draw profiles of supersaturation rate along the diffusion column. This means that different levels of metastability can be reached in the same experiment. In all of our experiments, at any time considered, supersaturation increases along the diffusion column from the $\mathrm{CaCl}_{2}$ reservoir to the $\mathrm{Na}_{2} \mathrm{CO}_{3}$ reservoir (Fig. 7), and so does metastability. This could explain why metastable aragonite crystallizes at the edge of the precipitation region closer to the source of $\mathrm{CO}_{3}{ }^{2-}$.

These results are in agreement with the idea that the mineral composition of calcium carbonate is influenced by the precipitation rate, as postulated by many authors (e.g., Bathurst 1975, Folk 1974). Given and Wilkinson (1985) and Chafetz et al. (1989) reported many natural examples where this influence was obvious. Some recent studies on calcium carbonate precipitation induced by the metabolic activity of bacteria (Buczynski and Chafetz 1991) have found a striking relationship between the medium viscosity and the phase that forms: whereas calcite crystallizes in more viscous media, where the precipitation rate is low, aragonite forms in liquid media, where precipitation is rapid. The growth rate of a precipitate depends directly on supersaturation. The results obtained could also help to explain the observation that in natural environments the rate of supply of carbonate ions determines whether calcite or aragonite precipitates. higher $\mathrm{CO}_{3}{ }^{2-}$ availability leading to aragonite crystallization and lower availability giving rise to calcite (Given and Wilkinson 1985). In fact, different rates of $\mathrm{CO}_{3}{ }^{2-}$ supply mean different supersaturation rates and, hence, different degrees of metastability. High supersaturation rates favor crystallization of metastable aragonite.

Crystal Growth.-Crystal growth takes place exclusively at the liquidsolid interface. This interface advances by incorporation of growth units from the surrounding solution to the active growth sites on the crystal surface. The number of active growth sites on an interface is directly related to its degree of roughness, and so is its growth rate (Sunagawa 1987). The roughness of an interface can have a kinetic origin, related to the number of crystallizing particles per unit area arriving onto it. In this way, a direct relation can be established between supersaturation in the system and roughness of the crystalline surfaces. Under increasing supersaturation, a smooth interface becomes rougher (Temkin 1971). The evolution from smooth to rough interfaces under the influence of varying supersaturation induces changes in the growth mechanism, the transition between different mechanisms being marked by supersaturation transitional values (Sunagawa 1981). At very low supersaturation levels, surfaces are smooth and the growth mechanism that dominates is screw-dislocation-controlled growth (Burton et al. 1951). Above a certain supersaturation critical value $\beta^{*}$ interfaces become rougher and crystals grow by lateral spreading of layers originated by two-dimensional nucleation (Kossel 1927: Stranski 1928). Another supersaturation transitional value, $\beta^{* *}$, marks the boundary between crystal growth controlled by two-dimensional nucleation and adhesive growth. At very high supersaturation, interfaces become even rougher, and any growth unit that arrives at the crystal surface is immediately incorporated. In such a situation, the rate of crystal growth is controlled not by surface phenomena, but by the diffusion of growth units from the bulk solution to the crystal surface. Although each growth mechanism is characterized by a different expression for growth rate, growth rate is, in all cases, a direct function of supersaturation (Chernov 1984). In the same way, different morphological developments are associated with each growth mechanism. While screw-dislocation-controlled growth gives rise to polyhedral crystals bounded by flat faces, crystals grown by two-dimensional nucleation mechanisms develop hopper (skeletal) morphologies. Continuous growth leads to development of rounded morphologies, dendrites, spherulites, and split growth phenomena.

The morphological evolution of calcite crystals in our experiments (Figs. 2,3 ) can be related to changes in the growth mechanism. As a consequence of the high supersaturation level at the nucleation time, growth of calcite crystals during the early stages is controlled by a continuous or adhesive growth mechanism. This results in development of dendritic crystals (Fig. 2). Subsequently, as a result of both the growth process and the decrease in supersaturation rates with increasing diffusion time, supersaturation progressively decreases. This leads to a transition to growth controlled by a two-dimensional nucleation mechanism. In this case crystals develop hopper or skeletal morphologies with flat facets. Finally, growth continues by filling up the skeletal crystal faces until the final polyhedral morphology is attained (Fig. 3). The last stages of the growth are controlled by a screwdislocation mechanism. 


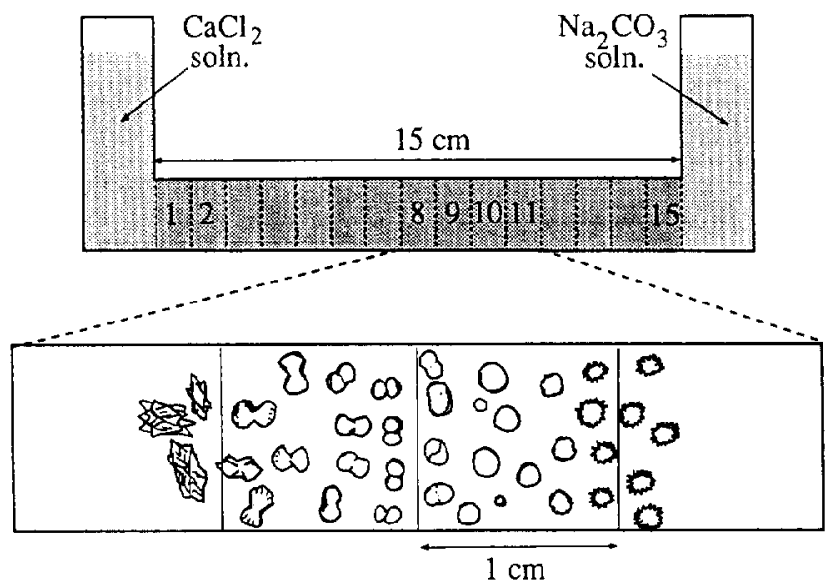

FIG. 8. Schematic representation of the precipitation region, showing the distribution of magnesian calcite morphologies along the column. The crystal morphologies and sizes refer to the sequence in Figure 5 . The spherulites at the extreme right of the figure are aragonite. The corresponding supersaturation profile at the nucleation time is that shown in Figure $7 \mathrm{~B}$. Mother solutions: $\mathrm{CaCl}_{2}(0.3 \mathrm{M})$ and $\mathrm{Na}_{2} \mathrm{CO}_{3}(0.3 \mathrm{~N})$.

\section{Results in Gels Doped with $\mathrm{Mg}^{2+}$}

Nucleation.-Our results confirm that magnesium affects the crystallization of calcium carbonate in two ways: it modifies the nucleation kinetics and it disturbs crystal growth. In our experiments, inhibition of nucleation leads to a significant increase in waiting time and in threshold supersaturation (Table 1). The way magnesium affects nucleation has been widely discussed (Lippmann 1960, 1973, 1982: Berner 1975; Reddy and Nancollas 19761. Hydrated magnesium is adsorbed onto the surface of calcite precritical nuclei and poisons the active growth sites. Although a magnesium ion may substitute for calcium in the calcite structure with little distortion, the fact that the dehydration energy is about $20 \%$ greater for $\mathrm{Mg}^{2-}$ than for $\mathrm{Ca}^{2}{ }^{2}$ strongly discriminates against magnesium incorporation. As a result. calcite pre-critical nuclei cannot become supercritical and hence grow spontaneously. However. at very high supersaturations this effect can be overridden. In fact. at high degrees of supersaturation, crystal surfaces become atomically rough, showing a much higher average density of growth sites. In such a situation. a much higher concentration of trace ion is required to poison the surface and stop growth (Chernov 1984). This is in agreement with the results shown in Table 1, where it can be observed that the effectiveness of $\mathrm{Mg}^{2-}$ in inhibiting $\mathrm{CaCO}_{3}$ nucleation decreases with increase in the concentration of the mother solutions and, thus, with increase in the supersaturation threshold.

Crystal Growth.-The role of magnesium ions during crystal growth is complex. As mentioned above. magnesian calcite crystals grown in doped gels show unusual morphologies. Crystals are bounded by rough surfaces and have rounded forms. The whole sequence (Fig. $5 \mathrm{~A}-\mathrm{H}$ ) from spheres built by misoriented crystal blocks to slightly elongated single crystals can be observed along the length of the column within the precipitation region (Fig. 8). By comparing the distribution of crystal morphologies with the supersaturation profile in Figure 7 it is clear that there is a direct relationship between supersaturation. morphology, and $\mathrm{Mg}$ content. The factors to be taken into account to explain the development of these morphologies are (1) characteristics of the interaction between magnesium ions and the calcite surface, and (2) supersaturation level during growth.

The presence of $\mathrm{Mg}^{2}$ + in the interstitial solution has the immediate consequence that the system reaches a very high supersaturation level before nucleation occurs. As a result, magnesian calcite crystals will grow in a very supersaturated medium. at least during the first stages of the growth process, and will show very rough surfaces. The morphological sequence observed in magnesian calcite crystals (from spheres to crystals with singular faces) is a consequence of very high supersaturation at the beginning of crystallization, and progressive decrease of supersaturation as crystal growth proceeds. However, the supersaturation rate was large enough to maintain the system within the range of supersaturations where crystals grow by a continuous mechanism. The whole morphological sequence corresponds to a continuous growth mechanism. Both $\mathrm{Mg}^{2+}$ adsorption and high supersaturation levels favor accumulation of defects during growth and, as a result, crystals are made up of misoriented blocks.

Similar morphological developments were found by Buczynski and Chafetz (1991) in bacterially induced $\mathrm{CaCO}_{3}$ precipitates. They ascribed these morphologies to the influence of metabolic activity of bacteria. Chafetz (1986) also proposed a bacterial origin for marine peloids and considered that the common pelleted texture of mudstones should also be attributed to bacterial activity. However, spherical morphologies in calcium carbonate can have diverse origins, and those interpretations should be reconsidered in the light of our results, especially where the phase that forms is magnesian calcite and crystallization occurs in fine-grained porous media.

McCauley and Roy (1974) found that aragonite spherulites grown in a gel doped with magnesium have an $\mathrm{Mg}$-rich core. On these grounds they proposed the existence of an Mg-rich phase epitaxially controlling the growth of aragonite. This is in contrast with our results, where aragonite crystals always contain less than $1 \mathrm{~mol} \% \mathrm{MgCO}_{3}$.

Chemical Composition and Morphology.-To understand the striking relationship between the $\mathrm{MgCO}_{3}$ content of magnesian calcite crystals and the morphology that they develop, we need to discuss briefly the factors that control incorporation of trace ions onto the surfaces of growing crystals.

Incorporation of trace ions into a crystal structure during growth is controlled by statistical selection. The continuous acts of attachment and detachment of particles (of both the principal component and of the trace ion) onto different sites at the crystal-solution interface during growth define the chemical composition on the crystal surface. According to the microscopic theory of trace-element trapping (Chernov 1984), the distribution coefficient of a trace element between the crystal and the solution has different values for different ranges of the growth rate. Changes in degree of supersaturation induce changes in growth rate and hence result in transitions between different distribution coefficients. Such behavior has been experimentally confirmed by a number of crystal growth experiments (Chernov 1984). Furthermore, there is experimental evidence that the distribution coefficient for trace elements that are adsorbed onto the crystal surface more weakly than the crystallizing macrocomponent. increases with the degree of supersaturation (Chernov 1970). Similarly, the experimental results obtained by Sawada et al. (1990) point to an increase in the distribution coefficient of $\mathrm{Mg}^{2+}$ for calcite when precipitation rate is very high. Many sedimentary petrologists have also suggested such an influence. Berner (1978) and Lahan and Siebert (1982) considered that the magnesium content in calcite is controlled by kinetically mediated coefficients that depend on rates of crystal growth. Lorens (1981) suggested that partitioning of trace and minor elements between aqueous solution and calcite can be influenced by growth rate. Reeder and Paquette (1989) have invoked this influence as one of the factors that can produce sector zoning.

The relationship found between the morphology of the magnesian calcite crystals (or the crystal aggregates) and their composition agrees with the behavior described above. The most complex forms correspond to the highest concentration of $\mathrm{MgCO}_{3}$ in the crystal structure. Furthermore, these morphologies correspond to the earliest stages of crystallization, i.e., they develop under the highest supersaturation levels. Later, supersaturation decreases as a consequence of growth, and simpler morphologies, with a smaller magnesium content, appear. The distribution of magnesian calcite morphologies within the gel column also agrees with the supersaturation profile. As mentioned above, supersaturation increases towards the $\mathrm{CO}_{3}{ }^{2-}$ 
reservoir, and the crystals with the highest content of magnesium occupy the zone of the precipitation region where supersaturation is highest (Figs. 7,8 ).

The fact that magnesian calcite crystals show compositional zoning, which in some cases can be sectorial or oscillatory (Fig. 6), can also be explained by non-equilibrium statistical selection of the surface composition. The concentration of a trace ion adsorbed on a crystal surface is determined by the atomic configuration of that surface; in other words, it is connected to its degree of roughness. Because interface roughness is orientation dependent (Sunagawa 1987), the concentration of trace ions incorporated by different faces may be different. This leads to the development of compositional sector zoning. Similarly, coupling between rate of growth and rate of supply of nutrients induces periodic changes in degree of supersaturation and thus in surface roughness. This leads to a self-organizational feedback responsible for the development of oscillatory zoning of $\mathrm{Mg}^{2+}$ in magnesian calcite. Such a mechanism is similar to that proposed by Wang and Merino (1992) for oscillatory zoning of trace elements in calcite and by Putnis et al. (1992) for oscillatory zoning of major elements in the $(\mathrm{Ba}, \mathrm{Sr}) \mathrm{SO}_{4}$ solid solution.

\section{ACKNOWLEDGMENTS}

We wish to thank Dr. Stephen Reed and David Newling for help with the electron microprobe analysis and compositional imaging and Ann Graeme-Barber for help in carrying out the lattice parameter measurements. We thank Dr. Tony Dickson, Prof. Enrique Merino, and Prof. Duncan Sibley for constructive comments on the manuscript. This work was partly supported by Dirección General Científica y Tecnica (DGCYT, Spain; Grant PB92-0998) and by the British/Spanish Joint Research Programme (Acciones Integradas).

\section{REFERENCES}

BATHuRST. R.G.C. 1975, Carbonate Sediments and Their Diagenesis, 2nd Edition: Amsterdam, Elsevier, $658 \mathrm{p}$.

BFRNER, R.A.. 1966, Diagenesis of carbonate sediments: interaction of $\mathrm{Mg}^{2+}$ in sea water with mineral grains: Science, ч. 153, p. 188-191

BERNER, R.A., 1975, The role of magnesium in the crystal growth of calcite and aragonite from seawaler: Geochimica et Cosmochimica Acta, v. 39. p. 489-504

Br:RNER, R.A., 1978, Equilibrium, kinetics, and the precipitation of magnesian calcite from sea water: American Journal of Science, v. 278, p. 1435-1477

Bischorr, J.L., 1968, Kinetics of calcite nucleation: magnesium ion inhibition and ionic strength catalysis: Journal of Geophysical Research, v. 73. p. 3315-3322.

BIsCHOFF, J.L., AND FYFF, W.S. 1968, Catalysis, inhibition, and the calcite-aragonite problem 1. The aragonite-calcite transformation: American Journal of Science, v. 266, p. 65-79.

Bischorf. W.P., Bishop, F.C., AND MackEvzll, F.T.. 1983, Biogenically produced magnesian calcite: inhomogeneities in chemical and physical properties; comparison with synthetic phases: American Mineralogist, v. 68, p. 1183-1188.

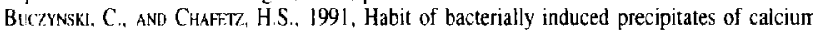
carbonate and the influence of medium viscosity on mineralogy: Journal of Sedimentary Petrology, v. 61, p. 226-233.

BiRToN. W.K.. CaBRERA, N.. AND Frank. F.C. 1951. The growth of crystals and the equilibrium structure of their surfaces: Royal Society (London). Philosophical Transactions. v. A243, p. $299-358$.

CHAl-TZ. H.S. 1986. Marine peloids: a product of bacterially induced precipitation of calcite Journal of Sedimentary Petrology. v. 56. p. 812-817.

CHAIETZ. H.S., RUSH, P.F., AND UTECH, N.M.. 1989, Geochemical and petrographic analysis of travertine precipitating waters and travertine deposits. Arbuckle Mountains, Oklahoma (abstract): American Association of Petroleum Geologists Bulletin, v. 73, p. 421.

CHE:RNov, A.A., 1970. Growth of copolymer chains and mixed crystals-trial and error statistics: Soviet Physics Uspekhi, ห. 13, p. 101.

CHr:RNov. A.A.. 1984, ed.. Modern Crystallography III. Crystal Growth: Berlin. Springer-Verlag, $517 \mathrm{p}$

CoDY, R.D., 1991, Organo-crystalline interactions in evaporite systems: the effects of crystallization inhibition: Journal of Sedimentary Petrology, v. 61. p. 704-718.

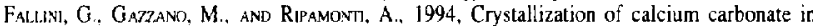
presence of magnesium and polyelectrolytes: Journal of Crystal Growth, v. 137. p. 577584.

FERNANDFZ-Diaz, L., 1989, Mecanismos de crecimiento en geles de carbonatos tipo aragonito: Ontogenia, transferencia de masa y criterios de cristalización [unpublished $\mathrm{Ph}$. D. thesis] Universidad Complutense de Madrid, 243 ?

Fol., R.L., 1974, The natural history of crystalline calcium carbonate: Effects of magnesium content and salinity: Journal of Sedimentary Petrology, v. 44. p. 40-53.

GIVEN. R.K., AND WILKNSON. B.H. 1985. Kinetic control of morphology, composition, and mineralogy of abiotic sedimentary carbonates: Journal of Sedimentary Petrology, v. 55, p $109-119$.

González. L.A.. Carpenter, S.J., And Lohmann, K C., 1992, horganic calcite morphology: roles of fluid chemistry and fluid flow: Journal of Sedimentary Petrology, v. 62, p. 382-399

Heises; W.M.M., 1985. The morphology of gel grown calcite: Neues Jahrbuch für Mineralogie, Monatshefte, v. 8, p. 357-371.

Henisch, H.K., 1988, Crystals in Gels and Liesegang Rings: Cambridge, U.K., Cambridge Liniversity Press, $197 \mathrm{p}$.

KrTavo, Y., and HoOn, D.W., 1962, Calciun carbonate crystals formed from sea water by inorganic processes: Oceanographical Society of Japan, Journal, v. 18. p. 141-145.

KTtavo, Y., and KanamoRI, N., 1966, Synthesis of magnesian calcite at low temperatures and pressures: Journal of Geochemistry, v. 1, p. 1-11

Kossel. W. 1927, Sur Theorie der Kristallwachstums: Akademie der Wissenschaften zu Göttingen, Nachrichten, v. 2, p. 135-145

LAHAK, R.W., 1978, A chemical model for calcite crystal growth and morphology: Journal of Sedimentary Petrology, v. 48, p. 337-344.

Lahan, R.W., and Siebert, R.M., 1982, A kinetic model for distribution coefficients and application 1o Mg-calcites: Geochimica et Cosmochimica Acta, v. 46, p. 2229-2237.

LeITMEIR, H., 1910, Zur Kenntnis der Carbonate, Die Dimorphie des Kohlensaurenkalkes. Teil: Neues Jahrbuch für Mineralogie. Heft I, p. 49-74.

Leitmeir, H., 1915, Zur Kenntnis der Carbonate. II Teil: Neues Jahrbuch für Mineralogie, Beilageband, v. 40 , p. $655-700$

LIFPMANN, F., 1960, Versuche zur Aufklänung der Bildungsbedingungen von Calcit und Aragonit: Fortschritte der Mineralogie, v. 38, p. 156-161

LipPMann, F., 1973, Sedimentary Carbonate Minerals: Berlin, Springer-Verlag, $228 \mathrm{p}$

LipPMANN, F., 1982, Nucleation and polymorphic precipitation of carbonate minerals: Estudios Geológicos, v. 38, p. 199-208.

LORENs, R.B., 1981, $\mathrm{Sr}, \mathrm{Cd}, \mathrm{Mn}$ and Co distribution coefficients in calcite as a function of calcite precipitation rate: Geochimica et Cosmochimica Acta, v. 45, p. 553-56I.

Mackenzie, F.T., Bischoff, W D., Bishop, F.C., Lojens, M., Schoomaker, J., and Wollast, R 1983. Magnesian calcites: Low-temperature occurrence, solubility and solid-solution behavior, in Reeder, R.J., ed., Carbonates: Mineralogy and Chemistry: Mineralogical Society of America, Reviews in Mineralogy 11, p. 97-144.

MCCAULEY, J.W., AND RoY, R., 1974. Controlled nucleation and crystal growth of various $\mathrm{CaCO}$, phases by the silica gel technique: American Mineralogist, v. 59, p. 947-963.

MoRSE, J.W., AND MACKENZI, F.T., 1990, Geochemistry of Sedimentary Carbonates: Amsterdam, Elsevier, Developments in Sedimentology $48.707 \mathrm{p}$

Muccl, A., 1986, Growth kinetics and composition of magnesian calcite overgrowth precipitated from seawater: quantitative influence of orthosphosphate ions: Geochimica et Cosmochimica Acta, v. 50, p. 2255-2265

Muccl, A., AND MoRsE, J.W., 1983, The incorporation of $\mathrm{Mg}^{2+}$ and $\mathrm{Sr}^{2+}$ into calcite overgrowths: influences of growth rate and solution composition: Geochimica et Cosmochimica Acta, y. 47, p. 217-233.

Nancollas, G.H., and Sawada, K., 1982, Formation of scales of calcium carbonate polymorphs: The influence of magnesium ion and inhibitors: Journal of Petroleum Technology. v. 34 , p. $645-652$.

Parker, S.C., TITLOYE, J.O., AND WATSON, W., 1993, Molecular modelling of carbonate minerals: studies of growth and morphology: Royal Society (London). Philosophical Transactions, v. A344, p. $37-48$

Prieto, M., Fernández-Diaz, L., AND Lóez-ÁndRes, S., 1989, Supersaturation evolution and first precipitate location in crystal growth in gels: Application to barium and strontium carbonates: Journal of Crystal Growth, v. 98, p. 447-460.

Prieto, M., Pitnis, A., and Fernandez-Diaz, L., 1990, Factors controlling the kinetics of crystallization: Supersaturation evolution in a porous medium. Application to barite crystallization: Geological Magazine, v. 127, p. 485-495.

Prete, M., Putnis, A., Arribas, J., ANd Fernandez-Diaz, L., 1992, Ontogeny of barite crystals grown in a porous medium: Mineralogical Magazine, v. 56. p. 587-598.

Preto, M., Putnis, A., Fernandez-Diaz, L., and Lopez-Ándres, S., 1994, Metastability in dif fusing-reacting systems: Journal of Crystal Growth, v. 142, p. 225-235.

Prieto, M. Viedma, C., López-Aceveido, V. Martín-Vival di, J.L., and López-Ándres, S., 1988 Mass transfer and supersaturation in crystal growth in gels: Journal of Crystal Growth, $v$ 92, p. $61-68$.

Putnis, A., Fernández-Diaz, L., and Prieto, M., 1992, Experimentally produced oscillatory zoning in the (Ba, $\mathrm{SrISO}_{4}$ solid solution: Nature, v. 358, p. 743-745.

Putnis, A., Prieto, M. and Fernandez-Diaz, L., 1995, Fluid supersaturation and erystallization in porous media: Geological Magazine, v. 132. p. 1-13

Reddy, M., and Nancollas, G.H. 1976, The crystallization of calcium carbonate. IV. The effect of magnesium, strontium and sulfate ions: Journal of Crystal Growth, y, 35, p. 3338

REDDY, M., AND WaNG, K.K., 1980, Crystallization of calcium carbonate in the presence of metal ions. I. Inhibition by magnesium ion at $\mathrm{pH} 8.8$ and $25^{\circ} \mathrm{C}$ : Journal of Crystal Growth. V. 50, p. $470-480$.

ReEder, R.J., and Paquetre, J., 1989, Sector zoning in natural and synthetic calcites: Sedi mentary Geology, v. 65, p. 239-247.

Sawada, K., Ogino, T., and Stzuni, T., 1990. The distribution coefficient of $\mathrm{Mg}^{2+}$ between $\mathrm{CaCO}_{3}$ polymorphs and solution and the effects on the formation and transformation of $\mathrm{CaCO}_{3}$ in water: Journal of Crystal Growth, v. 106, p. 393-399.

Stransir, I.N., 1928, Zur Theorie des Kristallwachstums: Zeitschrift für Physikalische Chemie, v. 136, p. $259-278$

SuNAGAWA, I, 1981, Characteristics of crystal growth in nature as seen from the morphology of mineral crystals: Bulletin de Mineralogie, v. 104, p. 81-87. 
Sinaciaka, 1., 1987, Morphology of minerals, in Sunagawa. 1. ed.: Morpholegy of Crytals: Tokyo. Terra Scientific Publishing Co., p. 509-587.

TeMkIR O.E. 1971. Phenomenological kinetics of the motion of a phase boundary: Soviet Physics, Crystallography, v. 15, p. 767-772

Trmioyt., J.O., Parker. S.C., ANi Mavi, S., 1993, Atomistic simulation of calcite surfaces and the influence of growth additives on their morphology: Journal of Crystal Growth, v. 131 p. $533-545$

WAl Tow, A.G. 1969. Nucleation in liquids and solutions, in Zettlemoyer, A.C.. ed., Nucleation: New York. Marcel Dekker, p. 225-307
W.NGi, Y.. AND MERINo. E., 1992. Dynamic model of oseillatory zoning of trace elements in calcite: Double layer, inhibition, and self-organization: Geochimica et Cosmochimica Acta, v. 56, p. $587-596$

Warrex, E.A.. And Smal.l.ey, P.C., 1994, North Sea Formation Waters Atlas: Geological Society of London Memoir 15, $208 \mathrm{p}$

Received 21 March 1995; accepted 8 September 1995 